\title{
TOWERS OF BABEL: THE CHAOS IN RADIO SPECTRUM UTILIZATION AND ALLOCATION
}

\author{
Nicholas JOHNSON*
}

The Federal Radio Commission (now the Federal Communications Commission) was created by Congress, in $1927,{ }^{1}$ to impose order upon the chaos of the radio spectrum caused by the electrical interference and the babble of overlapping voices. Forty-three years later, the interference and babble have eased, but the chaos remains.

The Communications Act of $1934^{2}$ charged the FCC with the efficient allocation among competing claimants of an important and scarce public resource-the electromagnetic, or radio, spectrum. ${ }^{3}$ The act was further designed to encourage the conservation of valuable frequencies, or spectrum space, while promoting the efficient development and utilization of the spectrum. This legislation was a response to the chaos that existed in the mid-Ig2os, when each spectrum user disregarded the interference he caused to others by his own use of the spectrum.

Over four decades have now passed, and it is time for a complete reappraisal of the FCC's policies, and its performance, in the area of spectrum management (conservation, development, utilization, and allocation). Has the current chaos of the radio spectrum been caused by the failure of the FCC to meet the growth of spectrum use with rational and consistent policies of spectrum management? If so, is there still a need for regulation of the spectrum by a central organization? Or is there a need for a reassessment of the FCC's structure and proper role as the manager of the spectrum? This article is addressed to these questions.

Part I of the article discusses the current FCC spectrum management-or

-B.A. 1956, LL.B. I958, University of Texas; Commissioner, Federal Communications Commission; author of the recent book How to TAIK BACK ro Your TELEvision SET (1970).

[Even those government officials who are capable of conceiving, researching, writing and editing articles almost always receive at least some measure of assistance with some or all of these tasks from any one of a number of available and anonymous staff assistants. It is generally impossible to identify the precise contribution of each. So it is in this case. Nevertheless, I want publicly to acknowledge my appreciation for the outstanding contributions to this article by my legal assistant, James Hoak (B.A. I966, Yale University; J.D. I969, Stanford University), almost immediately after his arrival on the job. Had he been even more persuasive he might have succeeded in compelling me to remove those defects that still remain, for which, of course, I accept full responsibility. N. J.]

${ }^{1}$ Radio Act of 1927 , ch. 169,44 Stat. II62.

${ }^{3} 47$ U.S.C. $\$ \S I_{5} \mathrm{I}-609$ ( $(964)$ ). For a history of the legislation and a description of the subsequent regulatory efforts, see Coase, The Federal Communications Commission, 2 J. LAw \& EcoN. I, I-7 (I959); Metzger \& Burrus, Radio Frequency Allocation in the Public Interest: Federal Government and Civilian Use, 4 DuQuesNe L. REv. 1, 3-47 (I965); Robinson, Radio Spectrum Regulation: The Administrative Process and the Problems of Institutional Reform, 53 Minn. L. REv. II79, II81-98 (1969); Note, The Crisis in Electromagnetic Frequency Allocation: Abatement Through Market Distribution, 53 Iows L. REv. $437,447-60(1967)$.

3 "The radio spectrum refers to the full range of radio waves that may theoretically be used to transmit information by electromagnetic energy." Levin, New Technology and the Old Regulation in Radio Spectrum Management, 56 AM. Econ. Rev. Papers \& Proc. 339 (Ig66). 
nonmanagement. This will focus on the two general tasks of the spectrum manager: regulation of spectrum utilization and allocation of frequencies. Management of spectrum utilization refers to the efforts to develop equipment and techniques which will allow use of higher-frequency parts of the spectrum and efforts to make more efficient the present use of the spectrum. Allocation of frequencies really involves two problems. The FCC decides which applicants will receive spectrum already allocated to a particular use. This choice among potential users is sometimes called "assignment." A second type of decision is between competing potential uses for the spectrum-whether a block of usable spectrum will be allocated for the use of land mobile radio, or broadcasting, or any of the other uses which technology is finding for the radio spectrum. Part II of the article discusses proposals that have been offered to promote efficiency and equity in the use of the spectrum. It will attempt to chart a course toward a system of spectrum management which, hopefully, will enable us to realize more fully the potential of the radio spectrum.

\section{The Chaos of Spectrum: The Crisis of Spectrum Management}

\section{A. Scarcity and the Electromagnetic Spectrum}

The electromagnetic spectrum is a unique resource. Rights to it are given to users for only a slight user fee. There is little incentive for the private sector to develop methods for more efficient use of the spectrum. The means of allocation of spectrum space is not based upon any rigorous measurement of value to the recipient or value to society. 4 The demand for the spectrum does not determine who receives the right to use it; neither price offered nor need demonstrated is sufficient. Rather, two centralized government bureaus-the FCC and the Office of Telecommunications Management (OTM)-perform the spectrum management task for all of society. 5 These bureaus, founded upon the concept of spectrum scarcity, ${ }^{B}$ must allocate this scarce resource between competing potential users and

\footnotetext{
A unique attempt to demonstrate value to society from a specific spectrum use was presented to the FCC in a report by Robert R. Nathan Associates, Inc., The Social and Economic Benefits of Tclevision Broadcasting, April 29, 1969 (unpublished manuscript on file at the FCC, prepared for the Association of Maximum Service Telecasters, Inc.). The report estimates the cost of television to socicty to be $\$ 8$ billion annually and the value to be from $\$ x g$ billion to $\$ 97$ billion-leaving a consumer surplus of $\$ \mathrm{Ir}$ billion to $\$ 8 \mathrm{~g}$ billion annually. Id. at 22-50. But see Webbink, How Not to Measture the Value of a Scarce Resource: The Land-Mobile Controversy, 23 FED. CoMm. BAR J. 202 (1969).

- The institutional framework of spectrum management is discussed in Metzger \& Burrus, supra note 2, at 47-70; Robinson, supra note 2, at Ir98-r2r4. See also Coase, The Interdepartment Radio Advisory Committee, $5 \mathrm{~J}$. LAW \& EcoN. I7 (Ig62). Just prior to the time of publication of this article, President Nixon proposed to Congress a reorganization plan creating a new Office of Telecommunications Policy. 6 Weekly Compilation of Prestdentiat Documents 156 (1970). The new White House office would function directly under the President. In addition to directing administration policies on telccommunications issues, the new office will, unless disapproved by either house of Congress, replace the OTM as the manager of spectrum used by the federal government. See N.Y. Times, Feb. 10, 1970, at 25, col. 5; Wall Street Journal, Feb. 10, 1970, at 7 , col. I. This reorganization proposal seems at the present time to have little relevance to the discussion and conclusions presented in this article.

'The problem with scarcity is that users, if not regulated, will not take account of the costs imposed
} 
uses by the criteria of what meets the "public interest." This task involves a unique blend of engineering, law, and economics, and the existing confusion in spectrum management is in many ways a result of the present incompatibility of these disciplines.

\section{Substitutes for Spectrum}

The conceptual basis for the current regulatory system-scarcity of spectrumobscures the fundamental spectrum management problems. In one sense there are always substitutes for spectrum. ${ }^{7}$ For example, transportation is a substitute for spectrum, as are the other factor inputs that radio displaces-labor, storage facilities, vehicles, wire and cable, and so forth. But as radio is often the only practical, and the far most efficient and cheapest, way of performing a task, substitutes are often not available without technological developments. The spectrum is therefore "scarce" only because it is cheaper than substitutes.

Greater and more effective use of the electromagnetic spectrum can be accomplished in two ways. Technical advances allow operation at increasingly higher frequencies. We currently use only a small portion of the potentially available spectrum. Our use is for the most part confined to the area below fifteen $\mathrm{GHz}$. $^{8}$ However, the use of regions as high as one million $\mathrm{GHz}$ is thought not to be impossible.

A second manner of spectrum development is to make more effective and efficient use of the currently usable spectrum by transmitting the same volume and quality of information in less frequency space or at a greater rate in the same frequency space. Examples are "channel sharing," where two distinct uses are accommodated on the same channel, or "channel splitting," where the size of a band assigned to a certain use is reduced. Although these technological developments may require operation at increased levels of interference, they must be discussed in terms of the spectrum as a whole, considering the costs and benefits to society, not to any single spectrum use.

\section{Spectrum Development and Government Regulation}

Technological achievements in recent years have opened up new areas of spectrum. Other advances have produced a more efficient allocation and utilization of the

on others in determining the value to them of the spectrum use. There is a need to choose among several applicants for limited spectrum, because a zero-price is artificially maintained for the scarce resource causing demand to remain above supply. The scarcity rationale for the existence of a national spectrum manager was seen by Justice Frankfurter in National Broadcasting Co. v. United States, 3 rg U.S. I90, 213 (1943).

"See Levin, There is Always a Substitute for Spectrum, ITU Telecommunications J., Jan. I969, at 33; Levin, The Radio Spectrum Resource, II J. LAw \& Econ. 433, 445-47 (Ig68); Levin, supra note 3 , at $340-41$.

${ }^{8} \mathrm{GHz}$ refers to "gigaHertz," or billions of cycles per second.

'See Johnson, New Technology: Its Effect on Use and Management of the Radio Spectrum, x967 Wash. U.L.Q. 521, 522. See genetally Prestdent's TASK Force on Communicattons Policy, A Survey of Telecommunications Technology (Staff Paper No. I, 1969). 
currently used spectrum. And discoveries and developments in microwave technologies, laser beams, solid state electronics, and nonatmospheric transmissions promise to provide practical use of even more of the spectrum. However, for two reasons, these technological developments do not decrease the need for intelligent spectrum management by a central government agency. First, improved spectrum management is needed if the advancements are to develop fully. For example, each of these threats to scarcity is also a threat to an economic interest which thrives on that scarcity. The development of these new techniques is retarded by the opposition of economic groups and by outdated regulatory practices that are captives of these entrenched interests.

Leland L. Johnson has written on the subject of the new spectrum technology:

So far as the technological possibilities are concerned, one has reason for optimism. Attractive trade-offs exist between spectrum resources and other resources; there are opportunities for greater sharing of frequency bands; improved nonatmospheric forms of transmission are available now and exciting developments are on the horizon. In the near-term, prospects are good that satellites will be able to share spectrum with microwave facilities without serious problems of interference; use of cable television as a substitute for atmospheric broadcast, even on a gradual basis, would give substantial immediate relief in the frequency regions now most congested. Through the 1970's use of higher frequency regions by satellites is promising. Depending in part on how these developments turn out, transistorized cable under water and on land could be employed as a supplement. In the more distant future, waveguides and laser pipes would meet any conceivable growth of point-to-point traffic over land.

The degree to which these technological possibilities will be exploited to make efficient use of both spectrum and non-spectrum resources is something else again. This will depend in good part on the nature of spectrum management. ${ }^{10}$

A second rationale for the continuance of a central agency as the nation's spectrum manager is that the developments which might produce the unlimited spectrum envisioned by radio scientists and engineers are not yet a reality. The United States Supreme Court, in the recent Red Lion decision, ${ }^{11}$ addressed the contention that technological developments undermined the rationale for regulation by the FCC. Mr. Justice White wrote,

Scarcity is not entirely a thing of the past. . . Portions of the spectrum must be reserved for vital uses unconnected with human communication, such as radio-navigational aids used by aircraft and vessels. Conflicts have even emerged between such vital functions as defense preparedness and experimentation in methods of averting midair collisions through radio warning devices. "Land mobile services" such as police, ambulance, fire department, public utility, and other communications systems have been occupying an increasingly crowded portion of the frequency spectrum and there are, apart from licensed amateur

\footnotetext{
${ }^{10}$ Johnson, supra note 9, at 542 .

11 Red Lion Broadcasting Co. v. FCC, 395 U.S. 367 (1969).
} 
radio operators' equipment, 5,000,000 transmitters operated on the "citizens' band" which is also increasingly congested. Among the various uses for radio frequency space, including marine, aviation, amateur, military, and common carrier users, there are easily enough claimants to permit use of the whole with an even smaller allocation to broadcast radio and television uses than now exists. ${ }^{12}$

So long as spectrum scarcity remains, the promise of eventual abundance is no justification for government's relinquishing its role as spectrum manager. The economic well-being and leisure enrichment of the nation require a national spectrum planner to ensure the efficient and rational utilization of a precious national resource. If the situation is changed by the ending of spectrum scarcity, the decision as to the future of spectrum management can be made at that time.

\section{B. The FCC and Spectrum Management}

\section{The Present System of Spectrum Management}

Confronted with the demands on the radio spectrum by commercial broadcasting, industrial use, and private use, the FCC, charged by Congress with bringing order out of the spectrum chaos of the Ig20s, has failed to develop virtually any consistent, rational policy of spectrum management. The decisions allocating spectrum between competing uses and users are made with little intelligent planning. Each case tends to introduce new criteria of allocation. Much of the value of predictability is denied to the applicants for spectrum. The resulting difficulty in planning is a tax on the economy and produces inefficiencies that no nation can long afford. ${ }^{13}$ Further, the Commission's failure to manage the radio spectrum more efficiently seriously affects economic development and leads to less than optimum resource allocation throughout the economy.

(a) Allocation procedures. The confusion and chaos of the present spectrum management is quickly seen in the FCC's allocation procedures, where spectrum rights are granted to one use or user to the exclusion of another. The potential user of spectrum must come to the spectrum manager. The manager must choose among the applicants on either a first-come, first-served basis or by finding one of the applicants to possess "superior qualifications of eligibility under the managers" allocational-distributional criteria." ${ }^{14}$ Because the FCC has no consistent principles of licensee qualifications, use of the latter test has produced an irrational and chaotic system. What is more, spectrum managers typically seem to use some

\footnotetext{
${ }^{12} I d$. at 396-98 (footnotes omitted).

${ }^{18}$ Professor Hyman Goldin has described the present system of spectrum allocation as "ritualistic, formalistic, wasteful and inefficient." Goldin, Discussion of "Evaluation of Public Policy Relating to Radio and Television Broadcasting: Social and Economic Issues" (Coase), 4I LAND Econ, I67, I68 (1965). Another author has observed that the FCC, "created years ago to protect the public resource of radio spectrum space, can be reasonably accused of squandering that resource in regulating the commercial television industry." Kohlmeier, The Regulatory Agencies: What Should Be Done?, ThE WastunGton Monthicy, Aug. 1969, at 43, 44. See also L. Kohlmeier, The Regulators 203-28 (I969).

${ }^{14}$ Levin, The Radio Spectrum Resource, supra note 7 , at 467 .
} 
aberrational combination of the two tests. Both the FCC and the OTM attempt to allocate spectrum on some basis other than first come, first served. However, the incumbent is given an edge over a challenging user, so that first come, first served is the usual result. For example, when spectrum is shared co-equally by two or more radio services, it is shared subject to the condition that new entrants protect from interference all those who are already using the spectrum band. Innovation is thereby stifled, for inefficient uses are not replaced and newly developed techniques are shuttled into the inferior areas of the spectrum.

The philosophy and policy used in allocating frequency space between competing uses is a bit more definite than the assignment of a frequency to competing users who both propose the same use. Blocks of spectrum are set aside for certain uses, and only applicants planning that use are accepted for consideration. The determination of how much spectrum, and which part of the spectrum, should be set aside for each user group is made by balancing two policies: the importance of the use and the technical necessity of spectrum for the function planned. Although this schematic system is followed more often in theory than in execution, it might be helpful to look more closely at it as an example of criteria that can be applied to solve a spectrum management problem.

(i) Importance of the use. The ranking of user groups has traditionally been determined by the relative public interest and importance of the different uses. On an international as well as national basis, broadcasting and safety services have usually received priority. Industrial services having an element of safety have followed second. Marine, aviation, and police are in the safety services group. Public utilities, such as electric and water companies fall in the second group, since breakdowns of service may affect public health or safety. Industrial concerns whose operations are hazardous are further down the list of priorities. At the bottom of the user group rankings are the small business concerns which rarely have great public safety aspects but whose prompt and efficient services benefit the public.

In allocating blocks of spectrum, the criteria for ranking the importance of specific uses are imprecise. Broadcasters and common carriers are usually favored over mobile radio because more people benefit from them. Nonbroadcast public allocations are usually favored over private allocations because of the importance of public safety. While these rules have some validity, they are too generalized to produce near optimum allocation results. For example, some small private businesses using spectrum for only economic purposes might provide a better or cheaper product with the addition of spectrum. This might be of more value to the public than the addition of more space to broadcasting. The important consideration should not be the relative absolute importance of incompatible uses but rather the comparative value to the public of a marginal unit of spectrum to each use. Only by comparing the value of spectrum for the additional broadcast station with the value of an equivalent amount of spectrum to mobile users, for example, can the 
true public interest be determined. That broadcasting is more important to the public than land mobile is irrelevant if there is already sufficient spectrum for the desired number of broadcasters but a shortage for land mobile operators. Another problem with the classifications of uses is the imprecision in distinguishing between geographic areas. This leads to the absurd situations where spectrum is reserved for the forest service in New York City or marine services in Nebraska.

(ii) Necessity of spectrum. Even though a particular prospective spectrum user might be engaged in activities of great importance to the public interest, it is necessary, in considering frequency allocations, to determine whether, as a technical matter, spectrum is required to perform the function. Police protection, for example, is one of the most important public services in the country. However, it does not follow from this fact alone that the police must be given all the spectrum they want. One must also determine for each individual police function whether spectrum is absolutely vital for the performance of the task. The allocation decision is made by considering these two criteria together; neither independently compels a grant of spectrum. For example, since wire lines are obviously impractical for communications to a moving vehicle, land mobile radio must be used for efficient and low-cost communications. But it does not follow that police agencies should have their own radio point-to-point systems connecting two immobile stations. For this purpose, wire communications are adequate. The Commission has determined as a general policy, following this reasoning, that the mobile use of radio by a small industrial concern, although low on the use priority list, is nevertheless more important to the public interest than is the point-to-point use of spectrum by the police. ${ }^{15}$ Stated another way, the relevant consideration is the cost and technical availability of a substitute for spectrum balanced against the political and social determination of this use's value.

(b) Spectrum management decisions. The FCC's decision in Lehigh Cooperative Farmers, Inc., ${ }^{16}$ illustrates the current chaos in spectrum management. In passing on a request for continued use of mobile radio, the Commission relegated the applicant to the more congested Business Radio Service rather than the Special Industrial Radio Service that he had been using. This decision was based upon the solemn finding that the livestock breeding business that he formerly owned was of higher priority than the dairy inspection business in which he was subsequently engaged. For the Commission to allocate valuable spectrum on the basis of which business it feels to be more important, without knowledge of the needs, efficiencies, contributions, and wants of the businesses, makes a mockery of the spectrum management task set forth in the Communications Act.

\footnotetext{
${ }^{15}$ In one of its few expositions of general allocation policies, the Commission in a 1949 Report and Order described some principles in its system of priorities for radio use in the nonbroadcast field. See General Mobile Radio Service, I3 F.C.C. Ixgo, Ir93-94 (I949).

${ }^{10}$ Io F.C.C.2d 315 (1967). On May 20, I970, the Commission acted to free more spectrum for longsuffering land-mobile users. See FCC 70-52I; FCC 70-5x9. This stop-gap action, devoid of planning and consideration of goals and ramifications, exemplifies the spectrum-management crisis.
} 
Other examples of the confusion and chaos in spectrum management are shown in the many recent channel-splitting decisions. ${ }^{17}$ To allow for a greater number of users in a given spectrum area, the Commission has often split the size of the individual channel assigned to each user. As technology develops, transmission can be made on much less space, and more users can be accommodated in the existing spectrum. But the need for greater spectrum space continues as the number of potential users grows and further channel splitting becomes impossible. ${ }^{18}$ There are really two steps to the channel-splitting procedure: Following the initial narrowing of the existing channels, the newly reclaimed spectrum is allocated to users. This allocation of the reclaimed spectrum is usually a political decision. The pressure for additional spectrum is so great that the Commission feels that it is only able to determine the direction of the greatest pressure and move with it. The situation is often so urgent that planning seems impossible. All the reclaimed spectrum is taken by those needs that must be filled immediately, so no experimental or nonordinary uses are benefited from the technology which makes ever dwindling parts of the spectrum more usable.

Yet efficient spectrum utilization requires planning by the spectrum manager. Conservation of spectrum, or stop-gap measures like channel splitting, are not enough. Rational, consistent planning is needed, that looks to the spectrum and the communications system as a whole. Only when all the needs and uses of spectrum are compared with all the currently usable spectrum can an efficient system emerge. Yet when confronted with spectrum management decisions, the Commissioners act more like editors than managers-for example, correcting punctuation and spelling or the infelicitous choice of words. There is no mechanism in the Commission's decision-making process which systematically presents alternative choices in any meaningful way so that action by the Commission can truly be called decision making. No pattern has developed from our decisions. No rules or policies or philosophies have been formulated. No consistently rational system of allocation has been proposed by those in a position to effectuate such a system. Too often decisions are the product of an ad hoc disposition reigning in the absence of any clearly articulated standards for spectrum allocation and utilization priorities.

\footnotetext{
17 These decisions, and my opinions, were as follows: Channel-Splitting in the Maritime Band, 156-162 $\mathrm{Mc} / \mathrm{s}$, I3 F.C.C.2d 874, 89I (1968) (concurring opinion); Frequency Allocations-450-470 Mc/s Band, II F.C.C.2d 648, 665 (xg68) (concurring opinion); Frequency Allocations-450-470 Mc/s Band, ro P.C.C.2d 885, 897 (1967) (concurring opinion); Channel-Splitting in the $450-470 \mathrm{Mc} / \mathrm{s}$ Band, I2 P \& F Radio Reg. 2d I596, 1598 (1968) (concurring opinion); Channel-Splitting in the $450-470 \mathrm{Mc} / \mathrm{s}$ Band, 8 P \& F Radio Reg. 2d 1629, 1633 (1966) (concurring in part and dissenting in part).

${ }^{18}$ For a description of the growth in spectrum use and the pressure for the future, see Telecommunication Science Paned of the Commerce Technical Advisory Board, U.S. Dep't of Conmerce, Electromagnetic Spectrum Utilization-The Silent Crisis: A Report on Telecommunication Science and the Federal Government 7-22, 38 (1966).

The President's Task Force on Communications Policy reported that the number of radio transmitters has grown at an average rate of over $17 \%$ per year and that the total of authorized, nongovernment transmitters increased from about 1.2 million in 1957 to over 6 million in 1967. Pnesident's TAsk Force on Communications Policy, Final Report ch. 8, at 5, in-i5 (ig68).
} 
Trenchant comments critical of the Commission's spectrum management procedures and decisions have come from a variety of sources-government reports, ${ }^{19}$ the academic community, ${ }^{20}$ and the professionals in the industries the Commission is to serve by its management decisions. ${ }^{21}$ These critics provide many insights into the crisis generated by the Commission's severe mismanagement in its frequency management role. The number and severity of these criticisms are clear warnings that the nation's spectrum managers-at least those with the power to act-are deep in a crisis from which they seem to have neither the competence nor the desire to escape. The social and economic implications of this nonmanagement of the spectrum are ominous.

\section{Inefficiencies from Spectrum Nonmanagement}

The danger and harm resulting from the nonmanagement of the spectrum may not be as obvious as the fact that a rational, systematic management does not exist. It is obvious that the ease with which spectrum users are accommodated in the spectrum affects their capital costs, so that ineffective management of the spectrum raises these costs and produces inefficiencies and distortions in the economic system.

\footnotetext{
${ }^{20}$ See, e.g., FCC, Report of the AdVSORy COMAItTeE for the LANd Mobile Radio Services (ig67); Office of Telecommunications Management, Executive Office of the President, A Report on Frequency Management Within the Executtve Branch of the Government 25 (1966); President's Task Force on Communications Policy, Final Report ch. 8 (ig68); President's Task Force on Comasunications Policy, The Use and Management of the Electromagnetic Spectrum (Staff Paper No. 7, rg69); TASK Force Report on Science AND TEChinology, presented to the President's Commission on Law Enforcement and the Administration of Justice, at 32-33 (1967); Telecommunication Scrence PANEL, stpra note 18 , at 37 .

${ }^{20}$ See, e.g., Coase, stipra note 2; Meckling, Management of the Frequency Spectrum, I968 WAsH. U.L.Q. 26; Metzger \& Burrus, supra note 2; Robinson, supra note I; Note, 53 Iowa I. REv. 437, 46r-68 (1967).

Professor Harvey J. Levin has written,

"New communications technology has required the re-examination of many policies and assumptions in recent years. So much so that the spectrum manager at the Federal Communications Commission and the President's Director of Telecommunications Management are starting to look like a harassed out-of-towner, racing down an up esclator, for that crowded subway about to leave Times Square on Christmas Eve. They may get there on time, but there must be an easier way."

Levin, supra note 3 , at 339 . See also Levin, supra note $x_{4}$.

${ }^{21}$ See, e.g., Joint Technical Advisory Commttee (JTAC), Radio Spectrum Utilization 8 (ig64); JTAC, Radio Spectrom Conservation I (I952). In another report, SPEctrum Engineering-The Key to Progress r6-I7 ( 1968 ), JTAC wrote,

"When we look at the tools on hand, we find that we are in the position of the farmer trying to do modern farming with yesterday's implements. Those implements did a good job in their day, but cannot meet the demands of tasks of the future.

***

"To sum up, there is a lack of-

-meaningful data on present use;

-full application of available tools;

-new analytical tools and procedures for long-range planning;

-procedures for flexibility in frequency assignment; and

-funds for spectrum engineering needed to develop techniques responsive to such tasks."
} 
But there are other, more subtle inefficiencies introduced by spectrum nonmanagement.

(a) The present spectrum management system has produced the repeated criticism that the FCC has failed to take account of economic considerations in the management of the radio resource. The Commission even today has no economists who are involved in the spectrum management process. In fact, the total lack of other than engineering standards in the process has caused existing standards to be vague, unintegrated, and virtually useless for marginal analysis. ${ }^{22}$

(b) Spectrum users find themselves subject to a number of incentives which work positively against efficient spectrum management, and the Commission has failed to modify that system. Thus, there is no incentive for a present user to economize on spectrum; he gets it free. There is an incentive to stockpile spectrum; it may be difficult to get in the future but costs nothing to stockpile. Acquisition of new spectrum is so uncertain that research and development activities are unnecessarily risky. Although technologically there may be many substitutes for spectrum, without the incentive to economize on its use these will never be developed.

(c) There is no present systematic provision for transferring spectrum from present users who give lower national return to new or alternative users who could provide higher national return. In fact there is no way the Commission can tell when its frequency distribution has achieved an optimum benefit flow, or how far present allocation deviates from the optimum.

(d) The Commission processes do not allow even private market efficiency, since the allocation of blocks of spectrum for a specific use prevents less profitable uses of the spectrum from being exchanged for more profitable ones. The Commission does not know if its block allocations are consistent with the most profitable and efficient use of the spectrum-although it is a virtual certainty that such is not the case.

(e) There is no natural incentive for more intensive use of spectrum-through sharing, acceptable levels of interference, or redesign of systems. Again, present users pay nothing for spectrum, and sharing is less satisfactory to them than monopolization.

$(f)$ The Commission does not have the capacity to evaluate adequately the proper mixture of uses of the new spectrum now becoming technically and economically useful at higher and higher frequencies.

$(g)$ There is no comparison of the relative benefits of governmental and nongovernmental uses of the spectrum, a comparison that must be made if judgments about optimum resource allocation are to be made.

\footnotetext{
${ }^{22}$ As discussed, the determination that must be made in allocating spectrum is the value of an additional unit of spectrum to one use compared with an additional unit to another use. The absolute value of spectrum to either use is irrelevant. This is what is meant by "marginal analysis."
} 
(h) The Commission continues to function under the unarticulated assumption that demands for frequency utilization will continue to increase by no more than small increments over the years to come. We must consider the possibility that our estimates are woefully inadequate-that, indeed, our present conceptions of use and administrative procedure are actually impeding mobile communications in this country. What if even half of all automobiles in this country were to be equipped with mobile radios? What if even one-tenth of the American people wished to carry mobile communications equipment with them? To borrow from the analogy of the telephone system, mobile communications may now be where cable communications were about rgro. We now have more than Ioo million interconnected telephones; each can reach any of the others in about thirty seconds; "party lines" have been virtually eliminated; security of communications is generally provided; licenses are not required; equipment can be installed and operating in a relatively short time. Why will Americans be satisfied with anything less in their mobile communications a few years hence? Are we ready for such an eventuality? How much are we daily losing in gross national product, corporate profits, and human satisfaction from our failure to anticipate such a system? Suppose mobile communications demand increases not by ten per cent, or two-fold, but ioo-fold, or rooo-fold. What kind of system should we have then? It is long past the time when these questions should have been addressed. Congress and the nation have a right to expect their spectrum managers to be concerned with the severe maladies in our administrative scheme which inhibit the answering of these questions.

\section{Reasons for Spectrum Nonmanagement}

Why has the FCC been unable to respond to the crisis in spectrum management with other than short-sighted, stop-gap measures? There are many reasons, but the major reason is lack of resources-money and competent personnel, primarily. Of course, it is not unusual for a government agency, when faced with a difficult problem, to plead inadequate resources. This plaint is often a way of concealing the fact that the agency lacks the ability ever to deal with the problem. And considering the magnitude of the needed additional financing in this case, such a charge will be levied, perhaps not unfairly, against the FCC in its role as spectrum manager. An additional million dollars, or the creation of another study group or research project, will do little to relieve the crisis. The Department of Commerce's Telecommunication Science Panel spoke of an annual budget of \$10 million to $\$ 50$ million just for spectrum research and policy studies. ${ }^{23}$ When compared with the entire FCC budget of approximately \$25 million-most of which goes for salariesthe dimensions of the problem are apparent. But despite the staggering size of these figures, additional resources are crucial for intelligent planning and research. The Stanford Research Institute, in a report to the FCC on the land-mobile spectrum crisis, wrote,

\footnotetext{
${ }^{28}$ Telecommunication Science Panel, supra note 18 , at 42.
} 
[I]t is clear that the FCC has not been provided with the resources for adequate management of the land mobile radio spectrum. Although it is not within the scope of our study, it is our overall conclusion that the lack of these resources is the key reason for complaints of congestion from land mobile users. Unless this lack of resources is remedied, the complaints from land mobile users will continue to increase in quantity and intensity. ${ }^{24}$

If lack of resources were the only cause of the spectrum management crisis, the solution-more money and people-could at least be recognized, if not provided. Unfortunately, that is not the case. There are other major causes of the troubles, including possibly the institutional structure of spectrum management. A first problem with the structure is the bifurcated system of regulation, with the FCC having jurisdiction over only the civilian use of the spectrum. There is no decision maker that takes an over-all look at the spectrum. A related problem is the impossibility of allocating between civilian uses and federal government uses when the spectrum management role is divided. There is no way truly to assess competing demands and needs comparatively, when the civilian and government users are never compared."

A second problem with the present institutional structure of spectrum management is the means by which users receive spectrum. Since users get spectrum, and can only have it taken away, in formal proceedings, they tend to compete for it and hoard it. Rather than spectrum being assigned to the user who needs it most at the moment, subject to frequent reappraisals of current needs and readjustments between users, the spectrum is assigned on a semi-permanent basis regardless of future needs. A third problem with the institutional framework is the lack of public understanding, interest, and scrutiny of the spectrum managers. ${ }^{26}$ As is the case in so many other areas that the government shrouds with secrecy, the crisis has to touch personally many members of the populace before any outcry is made.

Another cause of the current crisis in spectrum management is the system of decision making. One aspect of this system is the lack of criteria upon which decisions can be based. ${ }^{27}$ The only allocation standards provided by legislation are section 303 (g) ("encourage the larger and more effective use of radio in the public interest"), ${ }^{28}$ section 307 (b) ("provide a fair, efficient, and equitable distribution of radio" to as many communities as possible), ${ }^{2 \theta}$ and section 309 ("whether the public interest, convenience, and necessity will be served by the granting of" the

\footnotetext{
${ }^{34}$ Stanford Research Institute, A Study of Land Mobile Spectrum Utilization, Part B: An Analysis of the Spectrum Management Problem, Interim Report, March r969, at 6r (unpublished report on file at the FCC).

${ }^{25}$ See Metzger \& Burrus, supre note 2.

${ }^{20}$ See Rosenblum, Low Visibility Decision-Making by Administrative Agencies: The Problem of Radio Spectrum Allocation, I8 AD. L. REv. 19 (1965).

${ }^{27}$ See Friendly, The Federal Administrative Agencies: The Need for Better Definition of Administrative Standards, 75 HARv. L. REv. 863, 1055, I263 (1962); Jaffe, The Scandal of TV Licensing, Harpers MAg., Sept. I957, at 7r; Schwartz, Comparative Television and the Chancellor's Foot, 47 GEO. L.J. 655 (I959).

${ }^{28} 47$ U.S.C. $\$ 303(\mathrm{~g})(\mathrm{xg} 64)$.

${ }^{20} 47$ U.S.C. $\$ 307$ (b) $(1964)$.
} 
license).$^{30}$ This use of imprecise language, like "public interest," to cover up the total lack of criteria has been said to be "somewhere between a charade and criminal fraud." ${ }^{31}$ Of course, it is conceivable that the formulation of criteria for spectrum allocation is an impossible task. It is certainly much more difficult than normally assumed. For example, two criteria often given as the goals of spectrum management are minimizing interference and maximizing utilization of the frequencies. But these are not really allocation criteria because they are nearly exact opposites. The problem of frequency allocation is to balance these two opposites, and it is for that balancing that criteria are needed. ${ }^{32}$

The challenge of a system based on administrative determinations of priorities is to develop a rational basis for decision on social and economic grounds. This is the problem of developing criteria for decision making. Obvious factors to be considered in spectrum management decisions are contribution to the gross national product, the value of the equipment used, and the value to the nation of the service provided. But there are other factors to be considered; there is the problem of relative weight to be given to each factor; and there are problems inherent in any system of decision making based on priorities. First, it is hard to find a truly objective group to maintain a priority system. Second, to be truly accurate, local variations in relative value of the spectrum require separate determinations for each geographic area, and changes over time require frequent revisions. Third, a priority system of decision making must be based upon marginal values, a nearly impossible determination..$^{33}$

Another aspect of the decision-making process that adds to the spectrum management crisis is the lack of long-range, over-all spectrum planning. In many ways the Commission's actions are of the nature of crisis management-a crisis that would be unnecessary with adequate attention to policy planning and analysis. But there is no body-in or out of government-that is constantly looking at the spectrum management problems as a whole. There is virtually no opportunity for

${ }^{30} 47$ U.S.C. $\$ 309$ ( 1964$)$. This phrase was taken from early public utility regulation statutes. It has been said that it "means about as little as any phrase that the drafters of the Act could have used and still comply with the constitutional requirement that there be some standard to guide the administrative wisdom of the licensing authority." Caldwell, The Standard of Public Interest, Convenience or Necessity as Used in the Radio Act of 1927, I AIr L. REv. 295, 296 (I930). See also PREstDent's TASK Force, supra note 19, ch. 8, at 2I-22.

${ }^{81}$ Jones, Use and Regulation of the Radio Spectrum: Report on a Conference, 1968 WAsH. U.L.Q. 7I, 83, quoting Meckling, supra note 20. The OTM has even fewer criteria for spectrum management decisions than the FCC. Operating under delegated authority, it has no statutory authority of any kind. For a criticism of the "public interest" standard, see Reich, The Law of the Planned Society, 75 YAIE L.J. 1227, $1238-40$ (I966).

89 The conceptual difficulty in discussing criteria for spectrum management decisions shows the problem with discussing in technical terms something which is primarily an economic scarcity problem. See Meckling, supra note 20, at 28. See also Telecommunications Science Panei, supra note 18 , at $35-37$.

${ }^{83}$ See Hinchman, Use and Management of the Electrospace: A New Concept of the Radio Resource, in IEeE International Conference on Communications, Conference Record (Boulder, Colotado, June $9-I I, I g 69)$. 
anyone to step back from the petty considerations of individual case decisions and assess where the policies are leading. Perhaps in the end this, and most of the previously mentioned problems, derive from a lack of leadership. There is no public or private group willing and able to take national leadership in demanding better spectrum management. The subject is technical and unexciting; the process of decision making is secretive; and few people feel that they are intimately affected. It is not surprising that no one has come forward to arouse in the public a feeling that better management is needed. Yet such strong, vocal leadership is probably the only hope for action in the near future to deal with the crisis of spectrum management.

II

\section{Alternattves to the Present Spectrum Chaos}

Much has been written about alternatives to the present system of spectrum management. Although all the proposals present some problems in themselves and most are lacking in specifics, they are worth considering for the insights they give us into the present system. Any logical, reasonably comprehensive scheme would at least provide the certainty and predictability essential to the orderly functioning of government regulation of business, yet so often absent from the present spectrum management system.

\section{A. Institutional Changes}

\section{r. Market Allocation of Spectrum}

At present, all demands for the spectrum cannot be met. Choices must be made. If everyone who wants spectrum space could get it and use it as much as he chooses, the congestion would be such that no one's use would be very satisfactory. ${ }^{34}$ The FCC has been charged with regulation of this vast national resource by allocating parts of it to different users. Like most resources, spectrum is valuable, and those who have access to it benefit. Those who are precluded from using it must find alternatives or do without. In other parts of the economy, a user gains the right to use a resource-such as land, minerals, or water-by paying a price for that privilege. The price he pays is related to the benefit that he (and hopefully therefore society) gets from that use. Alternative users always have the opportunity to bid away those resources by paying a higher price. The absence of a functioning price system (or even a recognition of the relevance of pricing considera-

\footnotetext{
"Spectrum is a "common-property resource." Without regulation, users would lack the incentive to use the resource at a rate imposing costs on themselves. See Gordon, The Economic Theory of a Common-Property Resource: The Fishery, 62 J. PoL. Econ. I24 (1954); Levin, stlpra note 14 , at 454. Of course, regulation may be so inexact that it provides only a slight improvement over unregulated use. The lack of criteria for determining the threshold level at which the FCC must act to rclieve the congestion is discussed in the text accompanying notes 27-33 supra.
} 
tions in spectrum allocation) is particularly striking, especially as we face critical problems of over-all spectrum shortage and inefficient utilization. ${ }^{35}$

(a) The proposal. In reaction to the confusion and inefficiencies resulting from the present system of allocation, a group of economists led by Professor Ronald Coase have argued that the radio spectrum should be sold by the government to private users. Property rights in the spectrum would have to be defined, and the law would have to develop a system of enforcing these property rights. But after the initial sale from the government, transactions between users would be out of the control of a spectrum manager. Transactions of all sorts-sales, sharing, splitting, trades, and so forth-would be carried on with traditional institutions: the legal protection of property and the allocation of resources by the price system. An analogy is western land distribution at the end of the last century. Initially, the government delineated property lines, but ownership rights were then allowed to determine future land development.

In response to the argument that regulation is needed because of spectrum scarcity, the proponents of this position point out that all resources in the economic system are scarce, yet the normal solution is not government allocation. The traditional economic response to scarcity is to allow the pricing mechanism of the market to allocate scarce resources among competing claimants. The price system allocates land, labor, and capital among all claimants; broadcasters and other spectrum users must compete in the market for the nonspectrum resources they use. The advocates of spectrum allocation by the market mechanism believe there is no reason to treat spectrum differently from any other resource. ${ }^{36}$

(b) Merits of the market allocation proposal. The advantages of subjecting spectrum to market allocation were stated by Professor Coase in testimony before the FCC on December II, I959. ${ }^{37}$ He said that the pricing mechanism would bring to spectrum management the same advantages that it confers on other industries.

\footnotetext{
${ }^{85}$ While not advocating a complete market allocation approach to spectrum distribution, the Department of Commerce's Telecommunication Science Panel report said,

"Clearly some cost benefit relationship must ultimately be the decisive factor in choosing alternatives for advancement of system technology, intensification of frequency sharing, or exploitation of new regions of the spectrum. . . .

"Thus, for most of the nation's resources, the criterion that is used to discriminate less efficient configurations from more efficient ones is the value of the resource in the particular use in question. ...

"Frequency spectrum regarded as an economic resource is in no important respect different from most other economic resources. . . . A measure of the value of any particular parcel of land, or a barrel of oil, or a ton of steel, is generated in the process of selling these resources. No comparable measure of value is available in the case of frequency spectrum."

Telecommunication Science Panel, supra note 18 , at 35,37 (footnote omitted).

${ }^{36}$ The market allocation system is discussed in Jones, supra note $3 \mathrm{I}$, at $8 \mathrm{I}-97$.

87 Testimony before the FCC (en bane), vol. 4, at 895, Study of Radio and Television Network Broadcasting, No. I2782 (F.C.C., 1959). The same ideas as were presented in this testimony have been repeated by Professor Coase in written work. See Coase, The Economics of Broadcasting and Government Policy, 56 Am. Econ. Rev. Papers \& Proc. 440 (1966); Coase, Evaluation of Public Policy Relating to Radio and Television Broadcasting: Social and Economic Issues, 4I LAND EcoN. I6I (I965); Coase, supra note 2.
} 
First, the expensive, time-consuming allocation procedure now used would be eliminated. Second, the spectrum would be utilized with greater efficiency. Treatment of spectrum as a free good distorts the resource mix. Capital, labor, and land are used in different proportions to spectrum than they would be if spectrum had a price. No incentive currently exists to economize on spectrum use. If spectrum were costly to use, businesses would not stockpile it against the possibility of future need. And research and development on spectrum conservation would increase as businesses sought to minimize their spectrum costs. ${ }^{38}$

Other efficiencies in spectrum use would result. Spectrum users would need to consider alternatives uses of their spectrum-including the "opportunity costs" given by the possibility of converting the frequency into cash through sale. Through this process, the frequency would eventually seek the level of most efficient use. This movement of spectrum use from less efficient to more efficient users would require of the market system an additional quality-ease of transferability. The market system would facilitate change in frequency use by eliminating the need for formal proceedings before the FCC, thereby allowing direct negotiation between users. Spectrum users would evaluate their opportunity costs and substitutes for spectrum ${ }^{39}$ and negotiate with other spectrum users until the maximum benefit-cost ratio for the spectrum utilized by radio services was achieved.

A third advantage of market allocation of spectrum as seen by Coase would be its avoidance of any threat to freedom of the press inherent in the present allocation procedures for broadcast spectrum. Coase maintains that the only justification for the present system is the belief that the FCC must select only those broadcasters who will present "acceptable" programming. He believes that government determination of what is acceptable would squarely restrict freedom of the press. A fourth argument for market allocation is grounded on principles of equity. The sale of spectrum would avoid the arbitrary enrichment of certain users through the free disposition of public largess. ${ }^{40}$ This giveaway not only involves the threat of corruption and improper influence on the decision-making process, but also

\footnotetext{
${ }^{88}$ An example of the problems with the present management system is the fact that there is no orderly way to get commercial television on its own to use $3 \mathrm{MHHz}$ of spectrum per channel rather than the $6 \mathrm{MHz}$ now used, even though it may be technically feasible. The only way to get such a technical change would be for the Commission to say that as of 1975 all television channels will be on $3 \mathrm{MHz}$ of spectrum, and then let the scientists for private enterprise try to develop a system to conform to the requirement. But as of right now, the FCC does not have the staff or facilities to make the determination that such a limitation of spectrum is even remotely possible, and industry, without an incentive to engage in this type of research, will remain with $6 \mathrm{MHz}$. So nothing is done to free needed spectrum.

${ }^{80}$ Presumably users will define their spectrum value in terms of the cost of a spectrum substitute to them. Spectrum will then flow to those users who have the most expensive alternatives to spectrum, and therefore the greatest necessity for spectrum in their respective tasks.

${ }^{10}$ Describing the present system of allocation in which a broadeaster gets free a grant of spectrum for which he would be willing to pay millions of dollars, Professor Coase wrote, "This procedure results in an arbitrary enrichment of those private individuals who receive these favors from the FCC. The FCC, by its emphasis on the financial qualifications of the claimants, must inevitably tend to favor firms or individuals who are already financially well-endowed. The FCC is, in fact,
} 
deprives the public of payments by private industry for the use of a national resource.

(c) Problems with the market allocation proposal. Despite the simplicity and efficiency claimed by the market allocation advocates, several problems seem to remain.

(i) Engineering objections. Precise engineering definitions of spectrum rights would be necessary to the development of a market system in which private ownership and use of spectrum were adequately protected by the law. The classic rationale for regulation of an industry is based upon the need, shown by the economist Pigou, to consider the costs and benefits of externalities produced by the industry in any discussion of its efficiency. ${ }^{41}$ Absent government regulation each spectrum user would ignore the costs he imposed by his use on other spectrum users. But proper government regulation can force the internalization of these external costs. This internalization might also be achieved without the need for costly regulation, through the proper, comprehensive definition of property rights.

A serious engineering question exists as to whether property rights can be created in the radio spectrum. It would be difficult to define ownership of a segment of the spectrum so that ownership rights would not overlap and interfere with each other. The costs of defending exclusive rights would be high, but the courts probably could develop tort law sufficiently to protect the property rights. To make the owned spectrum segment precise and definite enough to be defended and transferred freely, spectrum engineers would need definitions in terms of outputs, not inputs. The important thing would be the power and frequency at the receiving, rather than transmitting, end of the communication. ${ }^{42}$ Despite the difficulties in creating property rights in the radio spectrum, a growing number of scholars have concluded that such a division is possible. ${ }^{43}$ But doubts remain. ${ }^{44}$

(ii) Economic and policy objections. Several economic assumptions made by advocates of the market allocation proposal must be examined closely. They assume that businesses will respond to economic incentives in a perfectly rational manner. For example, they envisage consistent profit maximizing decisions by corporate managers. But even with profit maximization as the primary goal of businesses, the market mechanism will not necessarily lead to greater efficiency and equity,

engaged in an anti-poverty campaign for millionaires." Coase, Evaluation of Public Policy, supra note 37 , at 165 .

"See A. Pigov, The Economics of Weifare (4th ed. 1932). But see Coase, The Problem of Social Cost, 3 J. LaW \& Econ. I (I960).

4 See Meckling, supra note 20, at 32; Robinson, stupra note 2, at 1248.

is See, e.g., De Vany, Eckert, Meyers, O'Hara, \& Scott, A Property System for Market Allocation of the Electromagnetic Spectrum: A Legal-Economic-Engineering Study, 2I STAN. L. REv. I499 (1969); Levin, supra note I4, at 457-58; Meckling, supra note 20, at 28-3I.

«See, e.g., Goldin, supra note 13, at 168; Hinchman, supra note 33; Robinson, supra note 2, at 1253-55. Even if it is true that engineering has advanced sufficiently to make the definition of property rights possible, it might be necessary to have some central authority define spectrum use because of the possibility of inefficient use at the edges of the spectrum segments where the neighboring regions overlap. 
for there is no certainty that spectrum use will flow to the best user from an economic and social standpoint. And if recent literature is correct, profit maximization may well not be the primary and/or constant goal of modern American business. ${ }^{45}$ The drive to maximize security and produce a safe, constant rate of return may be paramount. If so, the dynamics of the market may operate differently than the market proposal advocates believe.

Similarly, the proponents of the market allocation proposal may also err when they assume that consumers or users of spectrum can obtain the spectrum space they need by expressing their desires with money in the market. In order for consumer desires to be truly reflected in the market, the price system must function perfectly. The markets in America for industrial inputs are not perfect, but rather may inhibit consumer voices. It is probable, for example, that the major business firms, the large users of radio spectrum, manage and create consumer demand more than they respond to it. They may find it necessary to control demand so as to prevent the fluctuations that inhibit effective industrial planning. ${ }^{40}$ If larger companies in more concentrated markets are more likely to be able to control the demand for their products than others, the concentration likely to result in the communications industry from the use of the market mechanism would only add to the problem.

The spectrum market would deviate from the theoretical market of the price system advocates in another way. The existence of two different groups of spectrum "users" would inhibit the proper functioning of the dynamic spectrum market. For the market activities to represent consumer desires, all those affected by a spectrum use would have to be able to "bid" in the market. This means that the ultimate consumer of the spectrum service (for example, the television viewer), as well as the initial user (for example, the broadcaster), must be heard. But there are problems with the user-consumer's interest being reflected through the market mechanism. Radio services, for example, may provide social benefits not measured by the willingness or ability of the ultimate consumer to pay-even assuming there was some way he could pay. Television is desired by viewers, but the broadcasterusers of the spectrum would only pay an amount for the spectrum that would maximize advertising revenues. And there is no guarantee that viewer desires for the use of broadcast spectrum would equal the amount that broadcasters would pay to obtain the highest return of advertising revenues.

In certain industries government regulation is substituted for the pricing mechanism due to the high costs involved in the use of a free market. When market transactions involve a large number of people, the negotiation for the transfer of rights becomes too time-consuming and costly to be practical. The existence of two

aE See, e.g., J. Galbraitf, The New Industrial State passim (1967); Hetherington, Fact and Legal Theory: Shareholders, Managers, and Corporate Social Responsibility, 21 STAN. L. Rev. 248, 250, 258, 283 ( 1969 ); Robinson, stupra note 2, at 1251-52. But see Posner, Natural Monopoly and lts Regulation, 2 STAN. L. Rev. 548, 553-59 (I969).

${ }^{4}$ See J. Galbraith, supra note 45 , at $21 \mathrm{I}-32$. 
"user" groups for spectrum increases the number of people the market must consider if the market allocation proposal is to succeed. ${ }^{47}$ If user-consumers were dissatisfied with present uses of the spectrum, they would have to organize to make the market reflect their preferences for spectrum allocation. But this organizing may involve prohibitive costs-called "transaction costs." 48 These unorganized user-consumers are opposed in the market by existing, well organized spectrum users-often in corporate form ${ }^{40}$-with the wealth, power, and focused attention to secure favorable results. This disparity of power and resources, already apparent in current Commission allocation procedures, would become worse with the market allocation procedure. It would be hypocritical to tell the public that they have equal rights to those of the giant corporate users of spectrum since both can bid for its use.

The conclusion of the market allocation advocates that the pricing mechanism produces the most equitable and efficient allocation of resources is itself a normative, not an empirical, judgment. The government must interfere with the pricing mechanism in situations where the market can no longer be counted on for efficiency or equity, ${ }^{50}$ and this may well include the allocation of spectrum. We are seeing increasing challenges in this country to the conclusion that "good" public policy for microeconomic questions is necessarily that which produces the greatest efficiency ${ }^{51}$ Similarly, the presumption that pure competitive solutions are always "best" is being challenged. Those who urge free market solutions to resource allocation problems have as much responsibility to trace out the effects of their recommendations as do those who propose interference with market processes. To assume that market allocation of a good is the normal situation, to be departed from only in exceptional situations, is to determine an industry's goals and principles by considering only economic factors and ignoring the social impact of the industry.

The market allocation proposal ignores public policy considerations in its failure affirmatively to encourage "good" uses of spectrum. There is reasonable fear that without allocation by a government agency, "wrong" people will use the spectrum at "wrong" rates of use-"wrong" being defined as more than in the economist's sense

\footnotetext{
${ }^{47}$ Professor Hyman Goldin has argued that the multiplicity of users-the hundreds of thousands of licensees and millions of consumers-in the communications industry makes the market mechanism unworkable for frequency allocation. Goldin, supra note 13 , at I67-68.

${ }^{48}$ An analysis of transaction costs in another context indicates that these costs increase rapidly with the increase in the number of parties whose actions and desires must be coordinated for a desired arrangement to devclop. See Demsetz, Toward a Theory of Property Rights, 57 AM. Econ. Rev. PAPERS \& Proc. 347 ( 1967$)$.

${ }^{10} \mathrm{~A}$ corporation is a legal device for bringing together interests with capital and labor and other resources. The transaction costs have been reduced by the emergence of a large and well organized financial community, and are figured into the expected return on the investment.

${ }^{\circ 0}$ In economic terms, this occurs when marginal private utility diverges from marginal social utility. See Robinson, sttpra note 2, at $\times 256$, and sources cited there.

"Society's concern with cconomic efficiency as the ultimate good is symptomatic of what John Kenneth Galbraith calls "the modern morality" in which "St. Peter is assumed to ask applicants only what they have done to increase the GNP." J. GaLBRAIth, supra note 45 , at 408. Cf. Boulding, Economics as a Moral Science, 59 AM. Econ. Rev. I (r969).
} 
of "less efficient." Congress, for example, created the FCC to grant broadcast licenses in return for the dedication of some resources to the public interest. And although the Commission cannot, and should not, censor the content of radio and television shows, ${ }^{52}$ some review of broadcast programming standards is essential for regulation in the "public interest." 53

The present structure of spectrum allocation subsidizes certain activities by giving them free spectrum. The argument typically made against this subsidizing is that it is impossible to tell whether the favored activities really deserve this treatment. There is certainly merit in making all subsidized activities visible so that policy objectives can be reviewed. Yet perhaps we can take solace in the fact that this subsidy is no worse than many others. There are many other examples of the pricing system being ignored, purportedly to promote the public interest. Trucking firms, for example, are allowed to use the nation's highways by paying relatively small highway taxes, and airlines are allowed the free use of the airspace in exchange for their service to the public. But without regulation and subsidies, truckers might give less service, and airlines might not supply flights to many communities they are now required to serve. The generally accepted proposition that society benefits by having large trucking operations and air routes to smaller communities might be ignored in a perfectly rational market. I, of course, do not wish to defend subsidies, but I do think it is important to recognize that an installation of the market system for spectrum would have social ramifications. Once this is understood, the decision whether to retain the subsidy can be made on both economic and policy grounds.

${ }^{52} 47$ U.S.C. $\$ 326$. Although the subject of broadeast censorship is beyond the scope of this article, it should be mentioned that the unique structure of the broadcast industry, including cnormous barriers to entry, has caused a reappraisal of the role the First Amendment plays in broadeasting. See Red Lion Broadcasting Co. v. FCC, 395 U.S. 367 (I969); Barron, An Emerging First Amendment Right of Access to the Media?, 37 Gro. WASH. L. REv. 487 (1969); Barron, Access to the Press-A New First Amendment Right, 80 HaRv. L. REv. I64I (1967).

"See Rosenbloom, Authority of the Federal Communications Commission, in Freedom and RzSponstbility in Broadcasting 96 (J. Coons ed. 196r); Barrow, The Attainment of Balanced Program Service in Television, 52 VA. L. REv. 633 (1966).

The Supreme Court in Red Lion Broadcasting Co. v. FCC, 395 U.S. 367 (1969), in upholding the constitutionality of the Fairness Doctrine, tacitly approved the FCC's concern with program content. On several occasions the FCC promulgated rules or policies which placed affirmative programming obligations on broadcasters. See, e.g., FCC, Public Service Responsibility op Broadcast Iicensezs (I946), reprinted in Documents of American Brondcasting 125 (F. Kahn ed. 1968); Commission Policy on Programming, 20 P \& F RADio REG. Ig0I (I960); Editorializing by Broadcast Licensees, 13 F.C.C. 515 (1949).

Commissioner Kenneth $\operatorname{Cox}$ and I have attempted to develop a quantitative system for judging the performance of broadcast licensees seeking renewal of their licenses. Although our efforts have yet to win Commission majority approval, we feel that some standards (for example, minimum amounts of news and public affairs programming each day) are necessary for the determination that the licensec is serving the "public interest" through his use of the radio spectrum. See Renewal Standards: The District of Columbia, Maryland, Virginia and West Virginia License Renewals, 2I F.C.C.2d 35 (1969) (dissenting opinion); New York State License Renewals, I8 F.C.C.2d 268, 269 (1969) (dissenting opinion); Broadcasting in America and the FCC's License Renewal Process: An Oklahoma Case Study, I4 F.C.C.2d I (1968) (dissenting opinion); Renewal of Standard Broadcast and Television Licenses (Iowa 
(iii) Political and practical impossibility. The market allocation proposal is really no more than an academic suggestion, given the political realities. ${ }^{54}$ Two quite different groups of people would quickly raise objections to the implementation of the proposal. First, there are the many vested interests who benefit from the existing system. A market allocation system would probably cause an initial reallocation of licenses to the detriment of many incumbent licensees. Opposition from these licensees with nothing to gain from the change would be great. Second, those who conceive of the spectrum as a natural resource too precious to entrust to the private sector of society would object to the concept of property rights in the spectrum. Although many of these people have certainly been disappointed with the regulatory performance of the FCC, they may not yet be so discouraged as to turn over the radio spectrum to the private use of a few.

\section{Rental Payments for Spectrum Use}

Another proposal for the allocation of the spectrum similar to the market allocation proposal is the use of rental payments. There are many variations to this proposal-rental within established use groups or rental of the entire spectrum, constant rental payments or those varying with the value of the spectrum, and many others. Two variations deserve comment.

(a) Payments to the government. The federal government could reclaim the radio spectrum from the current users, and then rent it out to private interests-perhaps holding some back for use by public groups. The rental payments might be based on bids received at an auction, perhaps with some credit being given to the prior users of the spectrum on equitable grounds. This rental proposal is identical to the market allocation proposal except that the ownership rights are limited in time. It is therefore subject to the same criticisms as the market system of allocation. ${ }^{55}$

(b) Payments to the users of spectrum. Professor Harvey Levin has noted that newcomers to the spectrum would rather buy rights to use the spectrum than do without, so long as the payments are less than any spectrum substitute. But without a transfer system there is no way for those with spectrum of little value to them to get it to the newcomer who values it highly. Levin therefore proposes a rental system whereby newcomers would reimburse incumbents for any costs in vacating, sharing, or lending space to accommodate them in the spectrum. If the incumbent prefers not to accommodate the newcomer, he must compensate the newcomer for the costs of exclusion. This system would articulate the opportunity costs involved in spectrum use-for the incumbent, the cost of accommodating versus the payment of rent in the amount of the costs imposed on the rejected newcomer; for the newcomer, the rent in the amount of costs imposed on the incumbent in accommodating

\footnotetext{
and Missouri), rx F.C.C.2d 809, 8ro (r968) (dissenting opinion); Renewal of Standard Broadcast Station Licenses (Florida), 7 F.C.C.2d 122, 130 (1967) (dissenting opinion).

tid Cf. Coase, The Economics of Broadcasting, stpra note 37 .

to See text accompanying notes $4 \mathrm{I}-54$ supra.
} 
versus the cost of utilizing or developing an alternative to spectrum. ${ }^{56}$ Although this plan would be difficult to put into practice, the opportunity cost analysis shows the type of thinking that could be done by the spectrum manager. As such, this system of allocation deserves further study.

\section{Market Simulation by the Spectrum Manager}

(a) "Shadow pricing." In deciding whether to give spectrum to one user or another, or one use or another, the spectrum manager can simulate the market by attempting to balance the value of the spectrum to one user or use against the value to another. Using value and not ability to pay as the criterion for allocation, the manager can promote efficiencies without the "transaction costs" otherwise incurred by unorganized consumers of spectrum end products. ${ }^{57}$ Indeed, the manager can, by assigning a value to the consumers' normal "transaction costs," incorporate that consideration into his analysis and thereby represent the consumers' interests in the imaginary market.

Under the shadow pricing approach to spectrum allocation, the manager must first assign a value of spectrum to each use or user. This determination must not be the total value to the user, but rather the value at the margin; that is, each user's next-best alternative costs minus his spectrum costs would be the value to him. This can be seen as the cost to the user of being excluded from the use of spectrum and having to resort to his next-best substitute, and would theoretically be the price he would bid if the spectrum were sold at an auction. ${ }^{58}$ For example, assume a police department using spectrum can perform a certain task with a cost of $\$ 20$ million, but if spectrum were denied it, the same task would require $\$ 35$ million-the increase being additional police cars and men to offset the lack of mobile contact with the patrol cars. The spectrum value to this police department is $\$ 15$ million, the additional cost that it would have to bear if it were excluded from spectrum use.

Shadow pricing as a market simulation device has advantages over the market allocation proposal, ${ }^{69}$ but its execution poses several problems. To determine the actual value of spectrum to a user, one must know the exact price that he would be willing to pay for it. This would be difficult to ascertain in the abstract without the par-

\footnotetext{
${ }^{5 B}$ Levin, supra note 3 , at $343-46$.

${ }^{57}$ See text accompanying notes $47-49$ stipra.

${ }^{58}$ See Levin, supra note $I_{4}$, at $48 \mathrm{I}-85$. Market simulation becomes more difficult if the manager is committed to a "block allocation" system in which blocks of spectrum are allocated to use groups. This failure to discriminate among all users introduces a rigidity into the system but may be an administrative necessity. When choosing between competing uses, rather than users, the relevant comparison is between values to the entire user groups. The perfect allocation would equate the value of the spectrum to all the marginal users for all different uses. This would be analogous to the theory advanced by land mobile users that contributions by various uses to GNP should be a factor in allocations. See Jones, supra note $3 \mathrm{I}$, at 99.

In pure economic terms shadow prices would be the maximum demand prices by the users. This would be roughly equivalent to (a) a series of disequilibrium prices in a competitive market, or $(b)$ the sums which could be extracted by a discriminating monopolist who owned all the spectrum. Levin, supra note I4, at 435-36.

${ }^{80}$ For a discussion of some advantages, see Jones, supra note 31 , at 99-100.
} 
ticipants actually incurring the costs that they "bid." Until data utilization and economic predictions become more exact, shadow pricing as a system is probably impractical. However, as with the system for articulating opportunity costs, ${ }^{60}$ these problems should not discourage the further study of proposals that might further our understanding of proper decision-making processes.

(b) Consumer preference. One system of market simulation that might retain some values of the price mechanism without its inequities is a variation of a plan suggested by Peter Seeger. ${ }^{61}$ According to this plan, the consumer would voice his preference, not by spending money for goods or services, but by casting a ballot for one type of spectrum use or another. Each person could sell his vote, trade it, or combine it with others. In a society with vastly imperfect markets and great discrepancies in the distribution of wealth, this "market" of ballots may be the only equitable market for distribution of the public's radio resource.

\section{Structure of Decision Making}

(a) Manager. There have been many proposals to alter the structure of the spectrum managers. These usually include the proposal that the allocation decisions for both government and nongovernment users should be made by one manager responsible for coordinating and developing a comprehensive system. ${ }^{62}$ This could be implemented by transferring the spectrum management function of the FCC to a new executive department, ${ }^{63}$ or by consolidating spectrum management in the White House's OTM. ${ }^{64}$ On the other hand, some, including former FCC Chairman Rosel Hyde, have criticized any proposal for separating the spectrum management function from other FCC licensing and regulatory functions. Chairman Hyde views the different Commission functions as "inextricably interwoven," and feels that the complexities of modern communications require centralization, not fragmentation, of authority. ${ }^{65}$ Even if some consolidation of spectrum managers is deemed desirable, I feel that we should carefully consider the wisdom of creating additional executive departments and of giving control of the spectrum to the single largest user-the executive branch.

\footnotetext{
${ }^{\circ 0}$ See text accompanying note 56 supra.

${ }^{01}$ Secger, The Air Belongs to Everyone, Harv. Alumni Bull., April 28, 1969, at 53.

${ }^{82}$ See Metzger \& Burrus, stupra note 2, at 85-96; Minow, Suggestions for Improvement of the Administrative Process, I5 AD. L. REv. I46 (1963); Robinson, supra note 2, at I2I4-3I.

${ }^{63}$ President's TASK Force, supra note 19, ch. 8, at 5x-62.

ot See Variety, Sept. 24, I969, at 33, col. I. Secretary of Commerce Maurice Stans has urged that his department be allowed to take over all the functions of the OTM, but Secretary of Defense Melvin Laird said that this proposal does not offer "any significant advantages, but does present many disadvantages." He urged instead that the functions and authority of OTM be clarified and that both it and the FCC be provided with more resources for spectrum management. See Brondcasting, Oct. 20, 1969, at 62; Telecommunications Reports, Oct. I3, I969, at II.

For a discussion of the proposals for implementation of an agency separate from the FCC to be the spectrum manager, see Metzger \& Burrus, supra note 2, at 85-86; Note, supra note 2, at 457,47 .

${ }^{0 t}$ Address by Rosel Hyde, International Radio \& Television Society, in New York City, Sept. 23, rg69. For the opinion that planning and administration may be incompatible with regulation, see Reich, supra note $3 r$, at $r 240-43$.
} 
(b) Criteria. Any "system which does not use prices as a means of allocating frequencies must immediately face the criterion problem." ${ }^{\text {"66 }}$ But although the present system lacks the precision and predictability that might be achieved, abandoning it for a standardless system like the market allocation proposal, while logically attractive, provides no certainty that the performance of the spectrum users will improve. Instead, we should try to develop standards-which would include the consideration of "market value"-to make a reasoned choice between applicants. The adoption by the Commission or Congress of definite allocation procedures and criteria would provide some logic to a system unintelligible to most spectrum users and, when coupled with greater understanding of the economics of the industry, would lead to greater efficiency in spectrum use.

\section{B. Changes Within the Present Institutional Structure}

\section{Improved FCC Administration and Decision-Making}

A major unresolved question is whether the solution to the FCC's spectrum allocation and utilization problems lies with major institutional restructuring, or whether the reform of internal administrative procedures is a practical and adequate solution. Professor Glen O. Robinson has written:

Today in the field of spectrum allocation and management, the necessity to confront the complex issues of public policy, particularly to establish priorities of need among competing uses and to make hard choices among competing demands -or at least make acceptable, workable compromises—cannot be avoided by elaborate reorganization plans or sweeping changes in administrative processes. ${ }^{67}$

According to Professor Robinson, tangible resources-budget, staff, and effective leaders-are what is needed for administrative reform. But the current management has other, intangible needs if it is to develop a new approach to its task: the need to view spectrum problems as a whole; the need to anticipate and plan for future spectrum requirements; and the need to obtain better and more complete data on the use of the spectrum.

(a) View problems as a whole. A major stumbling block to the rational management of the radio spectrum is in part conceptual: Our communications problems are seen as myriad rather than unitary. Look at the goal of diversity of programming as an example. The issues involved in this broad policy-communications satellites, cable television, UHF development, direct satellite broadcasting in the upper UHF channels, pay television, regulation of network program ownership, alternative funding for noncommercial broadcasting, encouragement of local programming, copyright protection in broadcasting, duplication of AM radio programming on FM, and alternative uses for educational stations-can most comfortably be considered in isola-

\footnotetext{
${ }^{60}$ Meckling, supra note 20 , at 28 .

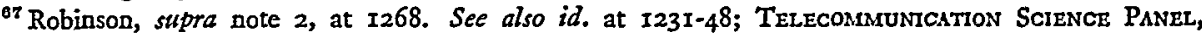
supra note 18 , at $38-39$.
} 
tion from one aonther. But we must forsake this comfort. Because our core communications problems-and solutions-derive from a burgeoning technology, we must view technology's various ramifications as parts of a whole.

Satellites, UHF television, and cable television have implications for television transmission, the number of channels available, and hence for possible improvement in programming. Satellites also have implications for frequency management and telephone and other home communication transmission, as does the cable network supplying cable television. Similarly, when one block of the spectrum is designated for a particular use, other more important uses not then being considered are foreclosed or their development impeded. We cannot, therefore, deal with each alternative in isolation, ignoring larger communications problems.

(b) Take a long-range view of the problems. Throughout all our communications problems runs the need for awareness, anticipation, and long-range forecasting. But the federal government has no coordinated administration of the communications field, and virtually no long-range planning efforts or research and development program at all. America's communications industries add substantially to our gross national product-at least $\$ 20$ billion from broadcasting-related activities alone. Yet the FCC is given only $\$ 25$ million-out of a federal budget of $\$ 200$ billion-to regulate this giant industry among others. It is understandable that the agency's activities are limited almost entirely to broadcast license grants and common carrier ratemaking. Frequency management is not possible without research and planning. And yet there is no central policy planning unit in the FCC's organization, ${ }^{68}$ leaving almost all social and technical research in communications to be done outside the government.

The concept of local programming by broadcasters is one example of policy planning failures. The benefits of local programming supposedly justify much FCC regulation-the cramped, interference-ridden $A M$ radio band, and the allocation of 420 extremely valuable megacycles to UHF television, to cite two examples. Yet how much local programming is really being provided? How much can profitably be provided? How much should be provided to promote community development? What are the opportunity costs of allocating the spectrum in this way? And how do the benefits compare with these costs? These are some of the questions that need to be answered before we can achieve efficient and equitable frequency management. But these are the kind of questions that can only be answered if the FCC and Congress are willing to give communications problems the funds and manpower for effective planning and research.

Another reason for the FCC's aversion to long-range policy planning is the

\footnotetext{
${ }^{08}$ The Department of Commerce's Telecommunication Science Panel proposed the creation of a research organization whose primary objective would be to furnish the spectrum managers "with the economic, social, and technical information and analyses necessary to provide a valid basis for judgments which affect the overall effectiveness of use of the spectrum." Telecommunication Science PANEL, sitpra note I8, at 39. See also id. at 39-42.
} 
Commission's conception of itself. The Commission tends to think of itself as a court, reacting only to those matters placed before it by interested parties pursuing their own economic interests. And after the issues for determination are specified, the Commission usually makes decisions that are based almost exclusively upon information and analysis supplied by these same parties. There is at best only limited recognition of the desirability of specifying all alternatives-and little capacity to evaluate them when they are presented to the agency from the outside. The Commission's consideration of the domestic satellite question is an example. Domestic satellites for the United States were first proposed, not by the FCC, but by $A B C$. The Ford Foundation subsequently filed a proposal that radically changed the frame of reference in which the question was being discussed-including the concept of a "people's dividend" from the massive public investment in the space program. But for the Ford Foundation's proposal, the Commission would probably not have considered these policy alternatives, and the proposals for adequate funding and interconnection of the Public Broadcasting Corporation would not have received what impetus they currently have.

This aversion to planning might have sufficed in simpler days, but the nation is now nearing an emergency in radio spectrum management. There is congestion in land mobile and uncertainty as to the future. There is ample spectrum in UHF but no certainty as to development opportunities. The AM band is nearly full; the FM band has never been properly explored and exploited. Industrial users, citizen band users, safety users, and other public users are hindered by inadequate management planning. The FCC should be planning and managing, not intensifying and exacerbating the problem. Every day our nation pays an increasing price in irretrievably lost GNP for our failure to manage properly our radio spectrum. Someday the current crisis of confusion and waste may reach such proportions as to bring it to national consciousness. As of now, with all the major crises facing this nation, it remains just another public resource vanishing in a quagmire of inept management.

(c) Obtain data on spectrum utilization. The nation's spectrum managers really know very little about the actual use of radio spectrum in the various bands. We must find out who is using the spectrum, at what times, and for what purposes. Data taken from licenses are not enough because there is little correlation between license data and actual use. Spectrum utilization data-data concerning actual use and economic value to the user-and modern data processing procedures and equipment are required. But the problems of spectrum management involve more than merely obtaining spectrum utilization data. Because the Commission replaces the free market forces in spectrum allocation, it needs economic analysis as a major tool in its allocation procedure. The Commission must seek to ascertain the opportunity costs for alternative spectrum uses. It must determine the "value" of alternative uses both to different users and to the economy. It must make a rational estimate of user 
"bids" in the imaginary market. It must develop efficient and intensive assignments with the help of spectrum advisory committees. And it must develop sharing and pooling arrangements.

At the present time there is not one economist on the Commission's staff who is principally concerned with spectrum allocation and management. A few tentative steps have been made to add a small number of economists to the spectrum management staff, and there has been some discussion of improving the Commission data bank. But unless far more is done, the FCC will not be able in the foreseeable future to make consistently intelligent decisions about spectrum based on sufficient data.

Before massive improvements in spectrum management should be made, a subtle problem, also requiring economic analysis, must be confronted: How much of the public's resources can justifiably be spent on spectrum management, and how can these additional resources be used most efficiently? A compromise must be obtained between the costs to the public of management improvement and the costs to the spectrum users of nonmanagement. This will involve determinations as to which management alternatives appear most fruitful (local, regional, or national allocation systems) and how much data is needed for each level of management obtainable. A related question is who should pay for the improvements in spectrum management. Presumably, there would be identifiable beneficiaries of improved government management. The decision might well be made that these beneficiaries, rather than the public as a whole, should bear the increased costs.

\section{Increase User Fees}

The imposition of user taxes or fees can achieve many of the economic efficiencies which would result from the use of the market mechanism in spectrum allocation. If we reject the market approach in favor of a central agency allocating spectrum on a case-by-case basis in order to insure maximum social benefits, it does not follow that the agency need use only abstract priorities to apportion licenses. The FCC now has a schedule of filing fees for licensees; ${ }^{69}$ greater economic efficiency might be gen-

\footnotetext{
${ }^{60} 47$ C.F.R. $\S$ I.IIII, .III3, .xII5, .III7, .xII9 (1969). On February $x 8$, I970, the FCC issued a notice of proposed rule making and invited comments on a new schedule of fees for spectrum users. See 35 Fed. Reg. 3815 (Feb. 27, I970). If approved, these fees, based largely on Commission cost, will return to the Treasury roughly 100\% of the Commission's r97I budget. This action was precipitated by the urging of the Bureau of the Budget and various committees of Congress over a period of several years. They felt that the Commission should internally generate more of the revenue for its budgetary needs. See Independent Offices Appropriations Act of 1952,31 U.S.C. $\$ 483$ (a) (1964); H.R. Rep. No. 9I-649, 9rst Cong. Ist Sess. 6 (1969); H.R. REP. No. 9I-3I6, 9Ist Cong., Ist Sess. 7-8 (1969).

The Executive Department has also expressed an interest in the Commission's fees, although its concern was less with fees as a revenue device and more with the economic effect of increased fees. The President's Council of Economic Advisers, in its annual report released in February I970, lamented the inefficiencies produced by the present method of spectrum allocation. They recognized that "it is difficult for any regulatory body to determine the most beneficial uses of a scarce resource." The Council concluded, "Without a market test [the FCC] has no way of being sure that its allocative
} 
erated by a better planned system of fees of much larger size. Many methods for computing user fees have been proposed: They could be set by market simulation or by competitive bidding; they could be based on the "size of the spectrum" being used (size being determined by spectrum band width, the time used daily, and the area covered by the transmission); they could be made proportional to spectrum availability, demand, and extent of use; they could be based on the value of the spectrum to the user; or they could be computed like a tax on the user's profits. ${ }^{70}$

Besides raising revenue to offset the operation of the agency, an increase in user fees would have other advantages. One great advantage would be the case of implementation. The FCC could, without additional legislation, increase its fee schedule, thus avoiding the delays and political pressures of the legislative process. Increased user fees would also provide a more equitable transition from the present system than a restructuring of the institutions of management.

Higher user fees would promote efficiency in spectrum use by reducing the monopoly rents which produce inequities and resource distortions. With a higher cost for spectrum, users would be forced to consider spectrum substitutes. Spectrum would be transferred from less efficient to more efficient users, and the higher fees would encourage more efficient utilization of spectrum, discourage stockpiling, and increase the research and development on spectrum-conserving techniques. Increased user fees might also eliminate in part the subsidies in the present systemsubsidies which enrich only spectrum users and the Washington attorneys who interpret the conflicting and confusing FCC allocation decisions. And most importantly, a significant increase in user fees would give the public some return on its lease of the airwaves.

\section{ConcLusion}

Many of the theories for institutional change of the spectrum allocation process have merit. Certainly the concepts of market allocation and market simulation deserve further study, if for no other reason than to give us a better understanding of what we should be doing under the present procedure. On balance, however, I would oppose the implementation of such structural changes-at least until I am convinced that the present system has no chance of success. I believe that it is unfair to judge

decisions are appropriate." Their proposal for the regulation of the radio spectrum, as for other "noncompetitive markets," was: "Here too the market should probably have a stronger influence on the allocative process. As an illustration, it might be possible to experiment with a mechanism reflecting the economic value of the entire spectrum. Such an experiment might involve a system of fees varying with the estimated value of particular frequencies and subject to repeated adjustment." Council of Economic Advisers, The Annual Report of the Council of Economic Advisers, in Economic RePORT OF THE PRESTDENT IOg-ro (I97o).

${ }^{70}$ One way to arrive at a fair tax or fee would be to allow the spectrum user a fair return on his costs or invested capital. The user would receive a profit on his tangible assets plus labor costs, but would receive no return on the spectrum which theoretically belongs to the public. Although this approach would create all the problems of public utility ratemaking-see Demsetz, Why Regulate 
the system of spectrum management contemplated by the Communications Act, since it has never really been tried.

The theory of the Communications Act was that the inherently oligopolistic structure of radio use necessitated a system of licenses for a limited term with no property rights accruing to the licensee. The radio spectrum was meant to be a resource owned and retained by the people. Their representatives-the Congress, and its delegated agency, the FCC-were to manage it. Private interests could use the spectrum as proxies for the public, but in return for the right to its use for private gain they were to "pay" by performance in the "public interest."71 Congress clearly saw that the use of the spectrum without monetary payment might produce large returns for the private users. But Congress contemplated that the spectrum users, in exchange for the spectrum, would not simply profit-maximize as do other businesses. The concept was that operation in the public interest would preclude profit maximization by the spectrum user, and that the difference between a publicservice operating level of profits and a theoretical level of maximum profits would be the price exacted for the use of the spectrum. It was thought that this system would produce benefits to the public in excess of the money that the public could have received from a sale of spectrum to a user with no public obligation.

This concept has failed for two reasons: the attitude of the spectrum users and the performance of the FCC. In arguing that they are primarily responsible to their shareholders, corporate spectrum users are asserting that they have a right to the free use of the spectrum. Yet this position is unsupported by the words and history of the Communications Act. The second barrier to the proper functioning of the Communications Act is the unwillingness of the FCC to enforce user performance in the "public interest." To be sure, the "public interest" is a nebulous concept. But the FCC has had nearly forty-five years to pour content into this soggy wine sack. And there is simply no basis whatsoever for assuming that it is satisfied by corporate conduct designed solely to maximize profits. In failing to adopt standards of spectrum use, the Commission has abdicated the role conceived for it by the developers of our communications system.

I realize that in preferring a "payment" from spectrum users in service rather than money, I am ignoring the efficiency value of subjecting the spectrum to the price system. I recognize that there are losses in this approach and would use higher

Utilities?, II J. LAw \& EcoN. 55 (I968); Posner, supra note 45-it would prevent the current situation where the transfer price of a license includes a large amount for the right to use the spectrum-often as high as $90 \%$ of the entire price in the case of broadcast licenses.

Some have voiced the opinion that user fees are required by law to be related to the cost of the FCC regulation. But as long as the fee is reasonable and cost-related in part, it will survive judicial scrutiny. See 5 U.S.C. $\$ \mathrm{I}_{40}$ (1964); Aeronautical Radio, Inc. v. United States, 335 F.2d 304 (D.C. Cir. 1964), cert. denied, 379 U.S. 966 ( 1965 ).

"This idea of extracting "payment" for a public resource by compelling operation in the public interest is not unprecedented. In exchange for lucrative air routes, airlines are forced to provide service between less populous communities, and railroads are forced to provide passenger service-often at a lossin exchange for the right to haul freight. 
user fees and shadow pricing to offset a portion of the losses. Public service "payment" promised by the user should be only one factor in the allocation decisionalong with the value to him and the value to society of this particular use of the spectrum, and his ability and willingness to pay the established user fees. The loss of efficiency in such a system, compared with a pure market allocation approach, would hopefully be more than made up by a communications system truly responsive to the needs and desires of the public. ${ }^{72}$

Before it can perform its rightful function as contemplated by the Communications Act, however, the FCC must face several managerial problems. It must overcome the acute lack of resources which would inhibit even a willing FCC. The Commission needs highly trained directors and staff with imagination and foresight. It must become willing to try new approaches to problems. But most of all the FCC must immediately face up to its tremendous responsibility for developing a rational spectrum system for the nation, and it must carefully rethink the problems and solutions it has blithely accepted for years.

In $1966,{ }^{73}$ I said that the coming year would be one in which America would "be forced to focus as never before on one of mankind's most fundamental needs: an understanding of what our communications systems can do for us-and to us." I singled out frequency management as among the most important issues before the Commission. Faced with the crisis of the congested spectrum, I hoped that we would "be charting planning efforts and research programs, looking for talent, and bringing kindred souls together in conferences and seminars." I asked, "What will be the response?" Now, over three years later, we can answer: There has been very little. Studies and records accumulate, but there has been no action. The problems of spectrum management-and most other technological communications problems-are no closer to resolution. The crisis is worsening. If we are ever to emerge, we must begin at once to develop a comprehensive system of efficient allocation and utilization policy. New funds and new ideas are needed. Both of these will be difficult to obtain. Yet how much better it is to seek to solve the problems now than to reflect in later years upon a communications system that might have been-while faced with another lost national resource ignored by advancing technology and national planning.

\footnotetext{
72 The Communications Task Force proposed a goal of spectrum management which would combine the economic and social principles that I have advocated: "to seek that combination of spectrum uses which offers maximum social and economic contribution to the national welfare and security." PrEstDENT's TASK Force, supra note I9, ch. 8, at 28. A corollary of this basic rule is this further goal: "to scek the continuing substitution of higher-valued spectrum uses for lower-valued uses-and the addition of uses whose net effect is to increase overall social or economic benefits-with due consideration of all imbedded capital investments." Id. at 28-29.

${ }^{78}$ Address to the Federal Communications Bar Association, Dec. 15, 1966, in Washington, D.C. This has been reprinted as Johnson, Crises in Communications: A Plea for Awareness and Response, in 6 Television Q. 2I (1967); Action, Jan. Ig67, at I4; and TV Communications, Jan. 1967, at 48.
} 